\title{
Membandingkan Persepsi Konsumen Berdasarkan Lingkungan Pekerjaan
}

\author{
RONI ANDESPA \\ Sekolah Tinggi Ilmu Ekonomi Riau (STIERIAU) \\ Jln. HR. Subrantas 57 Panam Pekanbaru 28293 Telp. (0761) 63237 \\ E-mail : akbar_stier@yahoo.com
}

\begin{abstract}
The research objective was to determine differences in the perception of consumers based on the type of work on quality, price and product packaging drinking water refill. The population is all refill drinking water consumers in the city of Pekanbaru, Riau. Where the sample in the study is that there are as many as 300 customers. The sampling technique used was non probability sampling method with Convenience sampling, considering where the population is large enough, then any consumer who is easy to find, and it was able to be sampled, then it has the right to be a respondent. This is done to diagnose the situation quickly and is simple and easy, because of the limited time in the fieldwork. Environmental distinguished work on 1. Groups of civil servants and private sector employees. 2. Groups of selfemployed, housewives and others. The results showed that there were significant differences between the consumer perception based on the type of work on the variable quality, price and product packaging drinking water refill.
\end{abstract}

Keywords: Perception, Consumers, Environment, Work

Pertumbuhan bisnis yang sangat pesat saat ini, ditandai dengan bermunculannya berbagai jenis usaha baik dalam skala kecil maupun skala yang besar dengan didukung oleh sumber modal dan sumber daya yang bervariasi, dimana keadaan ini memunculkan persaingan bisnis yang ketat. Kondisi yang ini secara menimbulkan tantangan tersendiri bagi pengusaha.

Para pemasar saat ini dituntut untuk lebih peka dalam mensikapi situasi dan kondisi serta keinginan konsumen akan suatu produk. Dengan banyaknya produsen air minum isi ulang yang yang muncul menimbulkan persaingan yang ketat di industri ini. Dimana bisnis air minum isi ulang saat ini sangat marak dan banyak ditemui tengah-tengah masyarakat. Usaha air minum isi ulang dapat dengan mudah dijumpai oleh konsumen disekitar tempat tinggalnya.

Tujuan pemasaran perusahaan adalah untuk mempengaruhi konsumen agar bersedia membelanjakan uangnya untuk mendapatkan produk yang ditawarkan perusahaan. Dimana pengusaha produk air minum isi ulang menginginkan agar produk yang dipasarkan dapat dikenal, diterima dan diminati oleh konsumen.

Para pengusaha produk air minum isi ulang tidak hanya menetapkan harga produk yang bisa terjangkau oleh konsumen namun juga menjaga kualitas produk air minum isi ulang yang dijualnya, sehingga menciptakan persepsi yang baik pada produk yang dijualnya tersebut. Konsumen saat ini senang dengan adanya produk air minum isi ulang, karena produk ini sangat praktis karena konsumen tidak perlu memasak air sendiri untuk memenuhi kebutuhan air minum.

Informasi tentang konsumen air minum isi ulang merupakan salah satu hal yang sangat penting didalam kegiatan untuk menetapkan strategi pemasaran, diharapkan dengan strategi pemasaran yang tepat akan meningkatkan volume penjualan.

Berkaitan dengan hal tersebut maka tugas pemasar adalah mencermati, mempelajari dan menganalisis pola dan tingkah laku konsumen beserta kondisi dan lingkungannya, dan lebih khususnya 
adalah mengetahui dan mempelajari sikap dan perilaku konsumen dalam pembelian suatu produk. Sehingga pemasar dapat menerapkan kebijakan dan strategi yang tepat untuk menarik minat konsumen membeli produk yang ditawarkan serta memperluas pasar.

Konsep pemasaran mengajarkan bahwa kegiatan pemasaran suatu perusahaan harus dimulai dengan usaha mengenalkan dan merumuskan kegiatan dan kebutuhan konsumen. Dengan adanya air minum isi ulang maka persepsi konsumen terhadap air minum isi ulang berdasarkan lingkungan pekerjaan juga berbeda-beda.

Dalam penelitian ini yang menjadi subjek penelitian adalah konsumen berdasarkan jenis pekerjaan, sedangkan yang menjadi objek penelitian adalah air minum isi ulang.

Batasan penelitian adalah konsumen yang dimaksud dalam penelitian ini adalah konsumen konsumen berdasarkan jenis pekerjaan di kota Pekanbaru.

Tujuan penelitian adalah untuk mengetahui perbedaan persepsi konsumen berdasarkan jenis pekerjaan atas kualitas, harga dan kemasan produk air minum isi ulang.

\section{Konsep Pemasaran}

Menurut Philip Kotler (2002:9) bahwa, salah satu tujuan pemasaran adalah untuk mengetahui dan memahami pelanggan sedemikian rupa sehingga produk atau jasa cocok dengan pelanggan dan selanjutnya menjual dirinya sendiri. Pemasaran hendaknya menghasilkan seorang pelanggan yang siap untuk membeli.

Menurut American Marketing Association yang di kutip dari buku Pemasaran oleh Lamb, Hair dan McDaniel (2001) "Marketing is the process of planning and executing the conception, pricing, promotion, and distributeon of ideas, goods, and service to create exchanges that satisfy individual and organization goals".

Menurut Asosiasi Pemasaran Amerika, yang dikutip dari buku Philip Kotler (2002:9), Pemasaran adalah proses perencanaan dan pelaksanaan pemikiran, penetapan harga, promosi serta penyaluran gagasan, barang dan jasa untuk menciptakan pertukaran yang memenuhi sasaran-sasaran individu dan organisasi.

Manajemen pemasaran terjadi bila sekurang-kurangnya satu pihak pelaku pertukaran potensial berpikir tentang sarana-sarana untuk melaksanakan tanggapan yang diinginkan oleh pihak pertama itu dari pihak lain.

Henry Simamora (2000:4) menyatakan bahwa Pemasaran Internasional (International Marketing) paling baik di jelaskan terlebih dahulu meninjau secara ringkas pemasaran dalam konteks Domestik.

Didalam konteks domestik, menurut Henry Simamora (2000:4), pemasaran merupakan proses manajerial dan sosial dimana individu-individu dan kelompok-kelompok memperoleh apa yang mereka butuhkan dan inginkan melalui penciptaan, penawaran dan pertukaran produk-produk yang bernilai dengan orang dan atau kelompok lain.

Suatu perusahaan mesti memantau aktivitas-aktivitas pamasaran pesaing domestik dan internasionalnya dan menyusun berbagai strategi pemasaran jangka panjang dan respon-respon kompetitif yang tepat.

Dengan demikian manajemen pemasaran merupakan perencanaan dan pengkoordinasian semua aktivitas tersebut untuk mencapai sebuah program pemasaran yang berintegrasi secara berhasil.

Konsep Pemasaran

Saat ini pandangan terhadap pemasaran telah mengalami perubahan dari sebelumnya. Pada mulanya pemasaran di pandang tidak jauh dari penjualan. Dengan timbulnya kesadaran untuk meningkatkan efisiensi.

Maka berangsur-angsur orang menyadari memuaskan kebutuhan pelanggan sangat penting untuk meraih kesuksesan.

Dalam pandangan Stanton (1995) 
dalam Husein Umar (2003:31), Stanton menyatakan bahwa pemasaran meliputi keseluruhan sistem yang berhubungan dengan kegiatan-kegiatan usaha, yang bertujuan merencanakan, menentukan harga hingga mempromosikan dan mendistribusikan barang dan jasa yang akan memuaskan kebutuhan pembeli, baik yang aktual maupun yang potensial.

Jangkauan pemasaran sangat luas, berbagai tahap kegiatan harus dilalui oleh barang dan jasa sebelum sampai ke tangan konsumen, sehingga ruang lingkup kegiatan yang luas itu di sederhanakan menjadi 4 (empat) kebijakan pemasaran yang lazim di sebut dengan bauran pemasaran (Marketing Mix) atau 4P dalam pemasaran yang terdiri dari:

\section{Produk (Product)}

Pengertian produk bagi konsumen selain merupakan benda yang mempunyai manfaat dan kegunaan juga merupakan suatu yang dapat ditawarkan kepasar untuk mendapatkan perhatian untuk di beli, digunakan atau di konsumsi yang dapat memenuhi suatu kegiatan atau kebutuhan.

Pengembangan sebuah produk menghasilkan perusahaan menetapkan manfaat-manfaat apa yang akan di berikan produk itu. Manfaat ini dikomunikasikan dan hendaknya di penuhi oleh atribut produk.

\section{Harga (Price)}

Harga adalah faktor utama yang harus di tentukan sebelum suatu produk di luncurkan ke pasar sasaran. Harga produk juga salah satu faktor penentu bagi permintaan pasar yang secara otomatis mempengaruhi volume penjualan.

Jika harga produk tidak dapat di jangkau konsumen, maka target penjualan yang telah di tetapkan tidak tercapai.

Harga menurut Husein Umar (2003:71) adalah sejumlah nilai yang di tukarkan konsumen dengan manfaat dari memiliki atau menggunakan produk atau jasa yang nilainya ditetapkan oleh pembeli dan penjual melalui tawar menawar atau di tetapkan oleh penjual untuk satu harga yang sama terhadap semua pembeli.

\section{Distribusi (Place) \\ Sebagian besar produsen} menggunakan perantara pemasaran untuk memasarkan produk khususnya barang dengan cara membangun suatu saluran distribusi yang meliputi sekelompok organisasi yang saling tergantung dalam keterlibatan mereka pada proses yang memungkinkan suatu produk atau jasa tersedia bagi penggunaan atau konsumsi oleh konsumen atau pengguna industrial.

\section{Promosi (Promotion)}

Konsep pemasaran tidak hanya membicarakan mengenai produk, harga produk dan mendistribusikan produk, tetapi juga mengkomunikasikan produk ini kepada masyarakat agar produk itu di kenal dan ujung-ujungnya di beli.

Boyd, Wolker, dan Larreche (2000:65) menyatakan strategi promosi merupakan sebuah program terkendali dan terpadu dari metode komunikasi dan material yang di rancang untuk menghadirkan perusahaan dan produkproduknya kepada calon konsumen, menyampaikan ciri-ciri produk yang memuaskan kebutuhan untuk mendorong penjualan yang pada akhirnya memberikan kontribusi pada kinerja laba jangka panjang.

\section{Perilaku Konsumen}

Perilaku konsumen yang tidak dapat di kendalikan secara langsung oleh perusahaan perlu di cari informasinya semaksimal mungkin. Perilaku konsumen memiliki kepentingan khusus bagi orang karena berbagai alasan, berhasrat mempengaruhi atau merubah perilaku itu, termasuk mereka yang berkepentingan utamanya adalah pemasaran, pendidikan dan perlindungan serta kebijakan umum.

Perilaku konsumen sangat menentukan dalam proses pengambilan keputusan membeli yang tahapnya di mulai dari pengenalan masalah oleh manusia, berupa desakan yang membangkitkan tindakan untuk memenuhi dan 
memuaskan terhadap kebutuhannya.

Semakin majunya perekonomian dan perkembangan zaman yang semakin pesat, harus beriringan dengan perkembangan strategi pemasaran yang harus dijalankan dan diterapkan oleh perusahaan.

Untuk itu perusahaan perlu memahami atau mempelajari perilaku konsumen dalam hubungannya dengan pembelian yang dilakukan oleh konsumen tersebut.

Dalam menentukan jenis produk atau jasa, konsumen selalu mempertimbangkan tentang produk atau jasa apa yang dibutuhkan, hal ini dikenal dengan perilaku konsumen.

Lamb, Hair, dan McDaniel (2001) perilaku konsumen merupakan proses seorang pelanggan dalam membuat keputusan membeli, juga untuk menggunakan dan membuang barang-barang dan jasa-jasa yang di beli, juga termasuk faktor yang mempengaruhi keputusan pembelian dan penggunaan produk.

Menurut Husein Umar (2003:64) perilaku konsumen adalah suatu tindakan langsung dalam mendapatkan, mengkonsumsi serta menghabiskan produk dan jasa, termasuk proses keputusan yang mendahului dan penyusuli tindakan tersebut.

Memahami bagaimana seorang konsumen dalam membuat keputusan pembelian, akan membantu seorang manajer pemasaran dalam banyak hal, terutama sekali mengestimasi jenis, bentuk dan merek dari sebuah produk yang akan dilemparkan kepasar, sehingga produk yang dibuat dapat disesuaikan dengan kebutuhan dan keinginan dari konsumen

Titik tolak untuk memahami perilaku pembeli adalah model rangsangan-tanggapan pemasaran dengan pembeli.

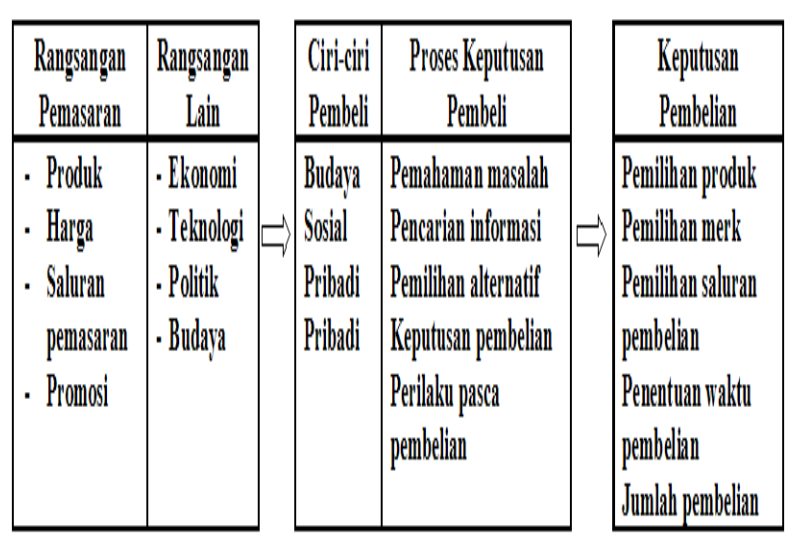

Gambar 1. Model Prilaku Konsumen, Kotler (2002)

Model Prilaku Konsumen Menurut Assael

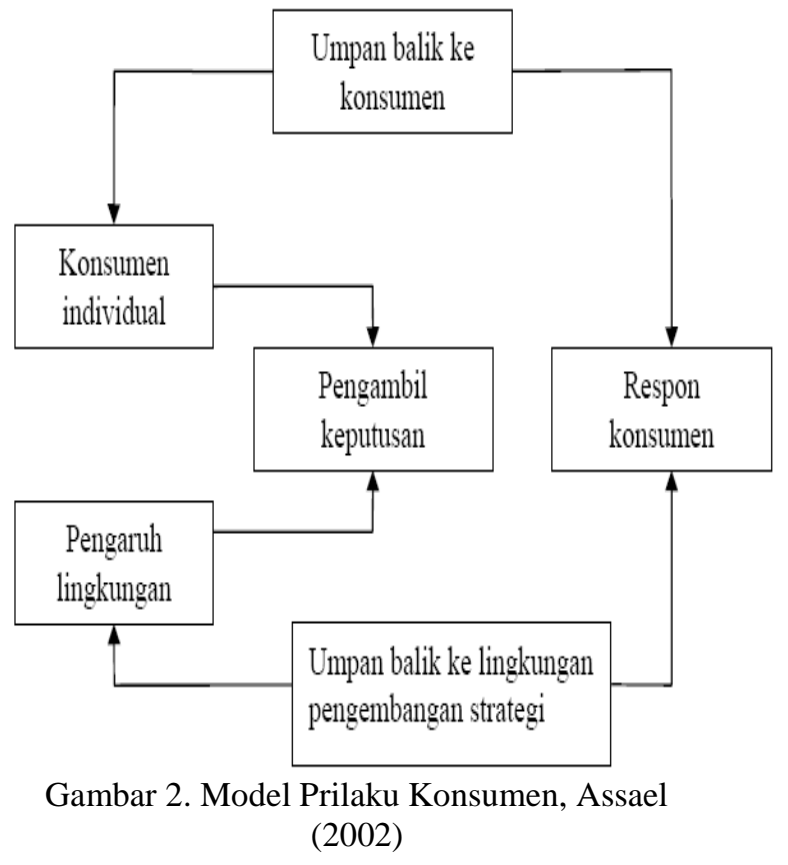

Model perilaku konsumen yang dikembangkan Assael (2002) bahwa proses keputusan konsumen dalam pembelian ditekankan pada tiga faktor yaitu:

a. Stimuli

Dimana stimuli menunjukkan penerimaan informasi oleh konsumen dan pemprosesan informasi terjadi saat konsumen mengevaluasi informasi dari periklanan, teman atau pengalaman sendiri.

\section{b. Karakteristik Pribadi Konsumen}

Karakteristik pribadi konsumen meliputi persepsi, sikap, manfaat serta karakteristik konsumen (demografi, 
kepribadian, gaya hidup).

\section{c. Respon Konsumen}

Respon dari konsumen adalah hasil akhir dari proses keputusan konsumen dan suatu pertimbangan yang menyeluruh sehingga melakukan pembelian terhadap produk.

Sikap dan perilaku konsumen juga merupakan bagian dari konsep perilaku konsumen yang lain. Untuk mengukur sikap dan perilaku konsumen dapat dengan model multi atribut.

Minat beli konsumen merupakan kecenderungan konsumen untuk membeli suatu merek atau mengambil tindakan yang berhubungan dengan pembelian yang diukur dengan tingkat kemungkinan konsumen melakukan pembelian (Assael, 2002).

Faktor-faktor yang mempengaruhi prilaku konsumen di dalam memutuskan untuk membeli adalah:

\section{Faktor Marketing Mix}

Para pemasar menggunakan sejumlah alat untuk mendapatkan tanggapan yang diinginkan dari pasar sasaran mereka, alatalat itu membentuk suatu bauran pemasaran.

Menurut Lamb, Hair, McDaniel (2001) bauran pemasaran mengacu pada paduan strategi produk, distribusi, promosi, dan penentuan harga yang bersifat unik yang dirancang untuk menghasilkan pertukaran yang saling memuaskan dengan pasar yang dituju.

Menurut Philip Kotler (2002:18), pengertian Marketing Mix adalah seperangkat alat pemasaran yang digunakan perusahaan untuk terus-menerus mencapai tujuan pemasarannya di pasar sasaran.

Jika sasaran pasarnya sudah ditentukan melalui riset pemasaran, maka perusahaan harus membuat suatu rencana yang baik untuk memasuki segmen pasar yang dipilih. Keputusan-keputusan didalam pemasaran dapat dikelompokkan dalam beberapa bauran:

a. Produk

Pengertian produk bagi konsumen selain merupakan benda yang mempunyai man- faat dan kegunaan juga merupakan suatu yang dapat ditawarkan kepasar untuk mendapatkan perhatian untuk di beli, digunakan atau di konsumsi yang dapat memenuhi suatu kegiatan atau kebutuhan.

Pengembangan sebuah produk menghasilkan perusahaan menetapkan manfaat-manfaat apa yang akan di berikan produk itu. Manfaat ini dikomunikasikan dan hendaknya dipenuhi oleh atribut produk.

\section{b. Harga}

Harga adalah faktor utama yang harus di tentukan sebelum suatu produk di luncurkan ke pasar sasaran. Harga produk juga salah satu faktor penentu bagi permintaan pasar yang secara otomatis akan mempengaruhi volume penjualan.

Jika harga produk tidak dapat dijangkau konsumen, maka target penjualan yang telah di tetapkan tidak tercapai, sedikit saja selisih harga dengan harga yang ditawarkan pesaing untuk pindah ke pesaing, karena harga merupakan faktor yang sangat sensitif bagi seorang konsumen dalam membeli.

Harga menurut Husein Umar (2003:32) adalah sejumlah nilai yang ditukarkan konsumen dengan manfaat dari memiliki atau menggunakan produk atau jasa yang nilainya ditetapkan oleh pembeli dan penjual melalui tawar menawar atau di tetapkan oleh penjual untuk satu harga yang sama terhadap semua pembeli.

\section{c. Promosi}

Pembahasan pemasaran tidak hanya membicarakan mengenai produk, harga produk dan mendistribusikan produk, tetapi juga mengkomunikasikan produk ini kepada masyarakat agar produk itu di kenal dan ujung-ujungnya di beli oleh konsumen.

Menurut Boyd, Walker, dan Larreche (2000:65) menyatakan strategi promosi merupakan sebuah program terkendali dan terpadu dari metode komunikasi dan material yang di rancang untuk menghadirkan perusahaan dan 
produk-produknya kepada calon konsumen, menyampaikan ciri-ciri produk yang memuaskan kebutuhan untuk mendorong penjualan yang pada akhirnya memberikan kontribusi pada kinerja laba jangka panjang.

Menurut Basu Swasta (2000) promosi adalah arus informasi atau persuasi satu arah yang dibuat untuk menciptakan pertukaran dalam pemasaran. Selain juga harus memperkerjakan, melatih dan memotivasi wiraniaganya.

2. Faktor Budaya

a. Budaya

Menurut Philip Kotler (2002:183) adalah merupakan penentu keinginan dan perilaku yang paling mendasar.

Menurut Lamb, Hair, McDaniel (2001) faktor budaya adalah karakter yang penting dari suatu sosial yang membedakannya dari kelompok kultur yang lainnya.

\section{b. Kelas Sosial}

Kelas Sosial menurut Lamb, Hair, McDaniel (2001) adalah menyebut kelas sosial dengan defenisi sebagai berikut merupakan sekelompok orang yang sama-sama mempertimbangkan secara dekat persamaan di dalam status atau penghargaan komunitas yang secara terus-menerus bersosialisasi di antara mereka sendiri baik secara formal dan informal, dan yang membagikan normanorma perilakunya.

Defenisi dari kelas sosial adalah pembagian masyarakat yang relatif homogen dan permanen yang tersusun secara hierarkis dan yang anggotanya menganut nilai-nilai, minat dan perilaku yang serupa.

Dimana kelas sosial menunjukkan preferensi produk dan merek yang berbeda dalam banyak hal.

\section{Faktor Sosial}

a. Kelompok Acuan

Kelompok acuan menurut Philip Kotler (2000:187) merupakan semua kelompok yang memiliki pengaruh langsung (tatap muka) atau tidak langsung terhadap sikap atau perilaku seseorang.

Orang sangat di pengaruhi oleh kelompok acuan, mereka sekurangkurangnya melalui tiga jalur: kelompok acuan menghadapkan seseorang pada perilaku dan gaya hidup baru.

Kelompok acuan juga mempengaruhi perilaku dan konsep pribadi seseorang. Dan kelompok menciptakan tekanan untuk mengikuti kebiasaan kelompok yang mungkin mempengaruhi pilihan produk dan merek aktual dari seseorang konsumen.

b. Keluarga

Menurut Philip Kotler (2000:188) merupakan organisasi pembelian konsumen yang paling penting dalam masyarakat dan ia telah menjadi objek penelitian yang luas. Anggota keluarga merupakan kelompok acuan primer yang paling berpengaruh.

Menurut Lamb, Hair, McDaniel (2001) keluarga merupakan institusi sosial yang paling penting bagi beberapa konsumen, karena secara kuat mempengaruhi nilai, sikap, konsep pribadi, dan perilaku pembelian.

\section{c. Peran dan Status}

Seseorang berpartisipasi kedalam banyak kelompok sepanjang hidupnya, keluarga, klub, ataupun organisasi. Kedudukan orang itu di masing-masing kelompok dapat di tentukan berdasarkan peran dan status.

Peran merupakan kegiatan yang di harapkan dilakukan oleh seseorang. Status merupakan masing-masing, dari peran tersebutlah yang nantinya akan menghasilkan status.

\section{Faktor Pribadi}

Keputusan di dalam pembelian juga di pengaruhi karakteristik pribadi sesorang yang terdiri dari:

a. Usia dan tahap siklus hidup

Beberapa karya terbaru telah mengidentifikasi tahap siklus hidup psikologis orang dewasa mengalami "perjalanan" dan "perubahan" sepanjang hidupnya. Seorang pemasar yang baik akan 
memberikan perhatian yang besar dan khusus pada perubahan situasi hidup-bercerai dan dampak situasi itu terhadap perilaku konsumsi sesorang konsumen.

b. Gaya hidup

Merupakan pola hidup seseorang didunia yang diekspresikan dalam aktivitas, minat dan opininya. Gaya hidup menggambarkan keseluruhan diri seseorang yang berinteraksi dengan lingkungannya.

c. Kepribadian dan konsep diri

Maksud dari kepribadian yaitu merupakan karakteristik psikologis seseorang yang berbeda dengan orang lain yang menyebabkan tanggapan yang relatif konsisten dan bertahan lama terhadap lingkungannya.

Kepribadian biasanya dijelaskan dengan menggunakan ciri-ciri seperti kepercayaan diri, dominasi, otonomi, kehormatan, kemampuan berorientasi, pertahanan diri, dan kemampuan beradaptasi.

Kepribadian dapat menjadi variabel yang sangat berguna dalam menganalisis prilaku konsumen, asalkan jenis kepribadian tersebut dapat diklasifikasikan dengan akurat dan asalkan terdapat korelasi yang kuat antara jenis kepribadian tertentu dengan pilihan produk atau merek.

Yang juga berkaitan dengan kepribadian adalah konsep diri seseorang. Pemasar yang jeli akan berusaha mengembangkan citra merek yang sesuai dengan citra pribadi pasar sasaran dari perusahaan, dan dengan kepribadian serta karakteristik khusus yang dimiliki konsumen.

\section{Faktor Psikologis}

Pilihan pembelian seseorang konsumen dapat di pengaruhi oleh empat faktor psikologis yaitu:

a. Motivasi

Motivasi merupakan kebutuhan yang cukup mendorong seseorang untuk bertindak melakukan sesuatu.

Tiga teori tentang motivasi:

Teori Freud

Dimana Sigmonund Freud mengasumsikan bahwa kekuatan psikologis yang membentuk perilaku manusia sebagian besar tidak disadari dan bahwa seseorang tidak memahami motivasi dirinya secara menyeluruh.

Teori Maslow

Abraham Maslow berusaha menjelaskan mengapa orang didorong oleh kebutuhan-kebutuhan tertentu pada waktu-waktu tertentu.

\section{Teori Herzberg}

Dimana Federick Herzberg mengembangkan teori motivasi dua faktor yang membedakan Dissatisfier (faktor yang menyebabkan ketidakpuasan) dan Satisfier (faktor yeng menyebabkan kepuasan).

\section{b. Persepsi}

Bagaimana seseorang yang termotivasi bertindak akan dipengaruhi oleh persepsinya terhadap situasi tertentu. Menurut Lamb, Hair, McDaniel (2001) proses dimana kita memilih, mengatur dan menginterpretasikan rangsangan tersebut kedalam sebuah gambaran yang memberikan makna dan melekat.

Menurut Philip Kotler (2002:198), persepsi merupakan proses yang digunakan seoang individu untuk memilih mengorganisasi dan menginterpretasi masukan-masukan informasi guna menciptakan gambaran dunia yang memiliki arti.

\section{c. Pembelajaran}

Menurut Philip Kotler (2002:198) merupakan perubahan perilaku seseorang yang timbul dari pengalaman.

Sebagian besar perilaku manusia adalah hasil dari belajar. Teori pembelajaran mengajarkan ke para pemasar bahwa mereka dapat membangun permintaan atas sebuah produk yang mengaitkannya pada dorongan yang kuat menggunakan petunjuk yang memberikan dorongan atau motivasi dan memberikan penguatan yang positif. 
d. Keyakinan dan sikap

Keyakinan mungkin berdasarkan pengetahuan pendapat atau kepercayaan kesemuanya itu mungkin atau tidak mungkin mengandung faktor emosional.

Keyakinan itu membentuk citra produk dan merk dan orang akan bertindak berdasarkan citra tersebut. Jika beberapa keyakinan mengenai tempat salah dan menghambat pembelian, perusahaan manufaktur akan berusaha meluncurkan kampanye untuk mengoreksi, serta memperbaiki keyakinan-keyakinan tersebut.

Adapun keyakinan menurut Philip Kotler (2002:199) yaitu merupakan suatu gambaran pikiran yang dianut seseorang tentang sesuatu hal.

Defenisi sikap menurut Philip Kotler (2002:200), sikap merupakan evaluasi, perasaan, emosional dan kecenderungan tindakan yang menguntungkan atau tidak menguntungkan dan bertahan lama dari seseorang terhadap suatu objek.

Kotler (2002) mengungkapkan bahwa berbagai teori tentang proses manajemen pemasaran, perilaku pengambilan keputusan dan perilaku konsumen dapat dibuat model strategi pemasaran. Sebagai inti dari model ini adalah perilaku pembelian. Perilaku pembelian dipengaruhi oleh tiga hal yaitu perbedaan individu, kondisi lingkungan dan usaha pemasaran.

Untuk mencapai keberhasilan pemasaran perusahaan perlu menyusun kebijakan pemasaran yang tepat sesuai dengan sasaran yang akan dituju. Marketing mix (bauran pemasaran) merupakan strategi pemasaran yang terdiri dari empat variabel (4P) yaitu produk, harga, promosi dan distribusi.

Mengingat keinginan konsumen yang selalu berubah, perusahaan dapat mengembangkan variabel-variabel bauran pemasaran sesuai dengan keinginan konsumen potensial. Sehingga dengan demikian usaha pemasaran tidak hanya bertumpu pada 4P saja tetapi dapat dikembangkan menjadi 7P.

\section{Persepsi Konsumen dalam Pemasaran}

Persepsi konsumen adalah sangat kualitatif, persepsi dapat dibentuk dan pembentukannya memerlukan waktu yang relative lama. Seorang manajer pemasaran mempunyai tugas untuk mengidentifikasi persepsi konsumen konsumen dan bila perlu membentuknya agar konsumen berubah dari kebiasaan membeli yang kadang-kadang saja berubah menjadi pelanggan tetap.

Dimana definisi persepsi konsumen menurut Kotler (2002) persepsi adalah proses bagaimana seseorang menyeleksi atau mengatur dan menginterprestasikan masukan-masukan informasi untuk menciptakan gambaran keseluruhan yang berarti jadi persepsi tidak hanya tergantung pada rangsangan fisik tetapi juga pada rangsangan yang berhubung dengan lingkungan sekitar dan keadaan individu yang bersangkutan.

Adapun definisi lain tentang persepsi adalah sebagai suatu atribut yang mendasarkan pada pengalaman untuk mendorong penerimaan suatu lewat lima indera manusia.

Definisi yang lain mengatakan bahwa persepsi didefinisikan proses pemulihan pengorganisasian dan interprestasi dari individu terdapat masukan informasi untuk menciptakan gambaran kenyataan suatu fakta dari pendapat tersebut dapat disimpulkan bahwa persepsi merupakan proses yang merupakan suatu aktifitas dalam mengindera, menyeleksi, mengorganisasi dan menginterprestasikan serta memberikan penilaian terhadap objek tertentu.

Persepsi akan dimulai dengan menangkap stimulus malalui penglihatan, pendengaran, penciuman, dan rasa. Namun tidak semua stimulus kita persepsi, karena manusia mempunyai keterbatasan. Kemudian individu menyeleksi stimulus yang menarik dan mengorganisir rangsangan yang diterima dengan akal sehat setelah itu barulah individu menafsirkan dan menilai.

Tiga faktor pembentuk persepsi seseorang terhadap rangsangan (Kotler, 2002) yaitu: 
1. Objek rangsangan.

2. Hubungan perangsang dengan lingkungan sekitar.

3. Karakteristik individu itu sendiri.

Konsumen yang karakteristiknya berbeda tentunya akan mempunyai kebutuhan yang berbeda pula. Dengan demikian konsumen yang mempunyai karakteristik yang berbeda, kemungkinan akan mempunyai persepsi yang berbeda terhadap stimulus produk. Pegawai negeri dengan wiraswasta yang mempunyai karakteristik yang berbeda kemungkinan juga akan mempunyai persepsi yang berbeda terhadap air minum isi ulang.

Dapat dibuat hipotesis untuk penelitan ini, yaitu, diduga terdapat perbedaan persepsi konsumen berdasarkan jenis pekerjaan atas kualitas, harga dan kemasan produk air minum isi ulang.

\section{METODE}

Populasi yang digunakan adalah seluruh konsumen air minum isi ulang di kota Pekanbaru, Riau. Dimana Sampel dalam penelitian yang digunakan adalah sebanyak 300 konsumen yang ada.

Teknik pengambilan sampel yang digunakan adalah metode non probability sampling dengan Convenience sampling, mengingat dimana jumlah populasi yang cukup besar, maka setiap konsumen yang mudah untuk ditemui, dan rasanya bisa untuk menjadi sampel, maka berhak untuk menjadi responden. Hal ini dilakukan untuk diagnosis situasi secara cepat dan bersifat sederhana serta mudah, karena adanya keterbatasan waktu dalam penelitian.

Lingkungan pekerjaan dibedakan atas 1. Kelompok pegawai negeri dan pegawai swasta. 2. Kelompok wiraswasta, ibu rumah tangga dan lain-lain.

Data yang digunakan adalah data primer yang diperoleh melalui penyebaran kuesioner kepada responden yang dijadikan sampel dengan pertanyaan tertutup dimana skala pengukurannya menggunakan skala 1 sampai dengan 5 (skala likert). Dimana angka 1 mewakili Sangat Tidak Setuju (STS) sampai dengan angka 5 mewakili Sangat
Setuju (SS). Analisis data dilakukan dengan menggunakan $t$ test independent sample.

\section{HASIL}

Setelah data dengan menggunakan metode kuesioner terkumpul, maka dilakukan pengolahan data dengan bantuan komputer, dan didapat outputnya sebagai berikut:

Tabel 1. Pengujian Perbedaan Varians Variabel Kualitas

\begin{tabular}{|l|r|r|r|r|r|}
\hline \multicolumn{2}{|l|}{ Pekerjaan } & $\mathrm{N}$ & Mean & $\begin{array}{c}\text { Std. } \\
\text { Deviation }\end{array}$ & $\begin{array}{c}\text { Std. Error } \\
\text { Mean }\end{array}$ \\
\hline Kualitas & $\begin{array}{l}\text { Kelompok Wiraswata, } \\
\text { Ibu Rumah Tangga } \\
\text { dan lain-lain }\end{array}$ & 180 & 4.0852 & .57154 & .04260 \\
\cline { 2 - 6 } & $\begin{array}{l}\text { Kelompok Pegawai } \\
\text { Negeri dan Pegawai } \\
\text { Swasta }\end{array}$ & 120 & 3.9417 & .57923 & .05288 \\
\hline
\end{tabular}

Sumber : Data Olahan Hasil Penelitian, 2012

Terlihat dari tabel 1 bahwa ratarata persepsi konsumen terhadap kualitas produk air minum isi ulang dengan pekerjaan wiraswasta, ibu rumah tangga dan lain-lain (rata-rata 4,0852) lebih baik dibandingkan konsumen dengan kelompok pekerjaan pegawai negeri dan pegawai swasta (rata-rata 3,9417).

Tabel 2. Pengujian Independent Samples Test Variabel Kualitas

\begin{tabular}{|c|c|c|c|c|c|c|}
\hline & \multicolumn{2}{|c|}{$\begin{array}{c}\text { Levene's Test for } \\
\text { Equality of } \\
\text { Variances }\end{array}$} & \multicolumn{3}{|c|}{ t:test for Equality of Means } \\
\hline & & $F$ & Sig. & $i$ & df & $\begin{array}{c}\text { Sig. } \\
\text { (2-tailed) }\end{array}$ \\
\hline \multirow[t]{2}{*}{ Kualitas } & $\begin{array}{l}\text { Equal variances } \\
\text { assumed }\end{array}$ & .123 & .726 & 2.119 & 298 & .035 \\
\hline & $\begin{array}{l}\text { Equal variances } \\
\text { not assumed }\end{array}$ & & & 2.114 & 252.809 & .036 \\
\hline
\end{tabular}

Sumber : Data Olahan Hasil Penelitian, 2012

Pada tabel 2 terdapat dua baris, baris pertama dengan asumsi bahwa varian kedua kelompok tersebut adalah sama, sedangkan pada baris kedua dengan asumsi bahwa varians kedua kelompok tersebut tidak sama. 
Untuk memilih baris mana yang akan digunakan sebagai uji, maka dilihat pada kolom uji $F$, jika signifikansinya > 0,05 maka asumsinya varians sama, sebaliknya jika signifikansinya $<0,05$ maka variansnya tidak sama.

Dari uji $\mathrm{F}$ menunjukan kalau varians kedua kelompok tersebut adalah sama ( $\mathrm{P}$ valuenya adalah 0,726 ), sehingga baris yang akan dibaca adalah baris pertama.

Dari kolom uji T menunjukan bahwa nilai $\mathrm{P}=0,035$ untuk uji 2-sisi. Karena $\mathrm{P}$ valuenya lebih kecil dari $\alpha=0,05$ yang berarti Ho ditolak, sehingga dapat kita simpulkan bahwa secara statistik terdapat perbedaan yang nyata antara rata-rata persepsi konsumen yang bekerja sebagai wiraswasta, ibu rumah tangga dan lain-lain dengan konsumen yang bekerja sebagai pegawai negeri dan pegawai swasta terhadap kualitas produk air minum isi ulang.

Tabel 3. Pengujian Perbedaan Varians Variabel Harga

\begin{tabular}{|l|l|r|r|r|c|}
\hline \multicolumn{2}{|l|}{ Pekerjaan } & $\mathrm{N}$ & Mean & $\begin{array}{c}\text { Std. } \\
\text { Deviation }\end{array}$ & $\begin{array}{c}\text { Std. Error } \\
\text { Mean }\end{array}$ \\
\hline Harga & $\begin{array}{l}\text { Kelompok Wiraswata, } \\
\text { Ibu Rumah Tangga } \\
\text { dan lain-lain }\end{array}$ & 180 & 4.0620 & .58404 & .04353 \\
\cline { 2 - 6 } & $\begin{array}{l}\text { Kelompok Pegawai } \\
\text { Negeri dan Pegawai } \\
\text { Swasta }\end{array}$ & 120 & 3.8903 & .60015 & .05479 \\
\hline
\end{tabular}

Sumber : Data Olahan Hasil Penelitian, 2012

Pada tabel 3 terlihat bahwa rata-rata persepsi konsumen terhadap harga produk air minum isi ulang dengan kelompok pekerjaan wiraswasta, ibu rumah tangga dan lain-lain (rata-rata 4,0620) lebih baik dibandingkan konsumen dengan pekerjaan pegawai negeri dan pegawai swasta (rata-rata 3,8903).

Tabel 4. Pengujian Independent Samples Test Variabel Harga

\begin{tabular}{|c|l|r|r|r|r|r|}
\hline \multicolumn{2}{|c|}{} & \multicolumn{2}{|c|}{$\begin{array}{c}\text { Levene's Test for } \\
\text { Equality of } \\
\text { Variances }\end{array}$} & \multicolumn{2}{|c|}{ t-test for Equality of Means } \\
\cline { 2 - 7 } & $\mathrm{F}$ & Sig. & \multicolumn{1}{|c|}{$\mathrm{t}$} & \multicolumn{1}{|c|}{$\mathrm{df}$} & $\begin{array}{c}\text { Sig. } \\
\text { (2-tailed) }\end{array}$ \\
\hline Harga & $\begin{array}{l}\text { Equal variances } \\
\text { assumed }\end{array}$ & 1.596 & .207 & 2.468 & 298 & .014 \\
\cline { 2 - 7 } & $\begin{array}{l}\text { Equal variances } \\
\text { not assumed }\end{array}$ & & & 2.455 & 250.355 & .015 \\
\hline
\end{tabular}

\section{Sumber : Data Olahan Hasil Penelitian, 2012}

Dari uji $F$ menunjukan kalau varians kedua kelompok tersebut adalah sama ( $\mathrm{P}$ value adalah 0,207$)$ dimana signifikansinya $>0,05$, sehingga baris yang akan dibaca adalah baris pertama.

Dari kolom uji $\mathrm{T}$ menunjukan bahwa nilai $\mathrm{P}=0,014$ untuk uji 2 sisi. Karena $\mathrm{P}$ valuenya lebih kecil dari $\alpha=$ 0,05 yang berarti Ho ditolak, sehingga dapat kita simpulkan bahwa secara statistik terdapat perbedaan yang nyata antara rata-rata persepsi konsumen yang bekerja sebagai wiraswasta, ibu rumah tangga dan lain-lain dengan konsumen yang bekerja sebagai pegawai negeri dan pegawai swasta terhadap harga produk air minum isi ulang.

Tabel 5. Pengujian Perbedaan Varians Variabel Kemasan

\begin{tabular}{|l|l|r|r|r|r|}
\hline \multicolumn{2}{|l|}{ Pekerjaan } & $\mathrm{N}$ & Mean & \multicolumn{1}{c|}{$\begin{array}{c}\text { Std. } \\
\text { Deviation }\end{array}$} & $\begin{array}{c}\text { Std. Error } \\
\text { Mean }\end{array}$ \\
\hline Kemasan & $\begin{array}{l}\text { Kelompok Wiraswata, } \\
\text { lbu Rumah Tangga dan } \\
\text { lain-lain }\end{array}$ & 180 & 4.0231 & .60099 & .04480 \\
\cline { 2 - 6 } & $\begin{array}{l}\text { Kelompok Pegawai } \\
\text { Negeri dan Pegawai } \\
\text { Swasta }\end{array}$ & 120 & 3.8486 & .62548 & .05710 \\
\hline
\end{tabular}

Sumber : Data Olahan Hasil Penelitian, 2012

Pada tabel 5 terlihat bahwa ratarata persepsi konsumen terhadap kemasan produk air minum isi ulang dengan pekerjaan wiraswasta, ibu rumah tangga dan lain-lain (rata-rata 4,0231) lebih baik dibandingkan konsumen dengan pekerjaan pegawai negeri dan pegawai swasta (ratarata 3,8486$)$.

Tabel 2. Pengujian Independent Samples Test Variabel Kemasan 


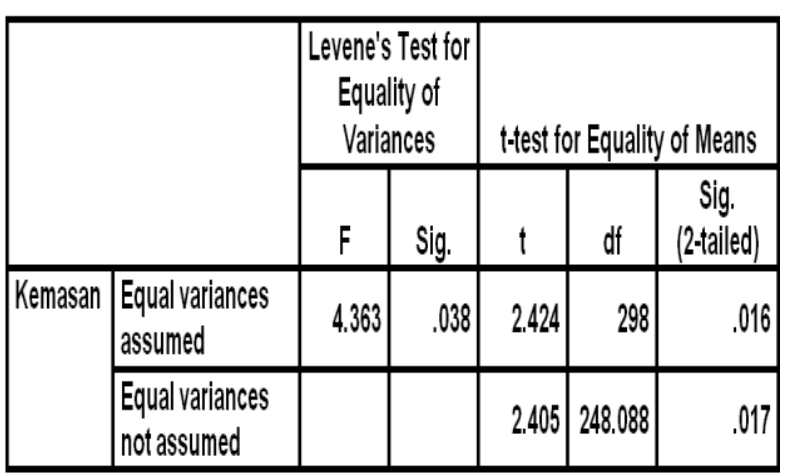

Sumber : Data Olahan Hasil Penelitian, 2012

Dari uji F yang ada pada tabel 6 menunjukan kalau varians kedua kelompok tersebut adalah tidak sama $(\mathrm{P}$ value adalah $0,038)$ dimana signifikansinya $<0,05$, sehingga baris yang akan dibaca adalah baris kedua.

Dari kolom uji T menunjukan bahwa nilai $\mathrm{P}=0,017$ untuk uji 2 sisi. Karena $\mathrm{P}$ valuenya lebih kecil dari $\alpha=0,05$ yang berarti Ho ditolak, sehingga dapat kita simpulkan bahwa secara statistik terdapat perbedaan yang nyata antara rata-rata persepsi konsumen yang bekerja sebagai wiraswasta, ibu rumah tangga dan lain-lain dengan konsumen yang bekerja sebagai pegawai negeri dan pegawai swasta terhadap kemasan produk air minum isi ulang.

\section{PEMBAHASAN}

Berdasarkan hasil analisis dan pengujian hipotesis yang telah dikemukakan sebelumnya, dapat dibuat pembahasan secara teoritis ataupun praktisnya.

\section{Implikasi Teoritis}

Untuk membangun persepsi konsumen atau pelanggan dapat dengan melakukan interaksi dengan pelanggan, langkah ini mengacu pada pentingnya berinteraksi dengan pelanggan dalam upaya membangun hubungan melalui berbagai alat komunikasi dan teknologi. Hal ini diperlukan karena hubungan hanya dapat mengembangkan dan dipertahankan jika ada komunikasi dengan pelanggan tentang kebutuhan mereka, persepsi dan keinginan. Ini melibatkan bagaimana perusahaan dapat mengembangkan metode komunikasi proaktif dengan pelanggan mengenai dan mencoba untuk memulai dialog dengan pelanggan.
Gunakan apapun yang dapat dibuat dari teknologi, tetapi hal ini tidak penting menurut Brunjes \& Roderick didalam Brink Annekie (2009).

Organisasi bisnis dengan informasi yang akurat tentang persepsi pelanggan, tentang mutu produk, akan dapat membuat keputusan yang lebih baik, khususnya di dalam memberikan pelayanan yang lebih baik kepada para pelanggan sehingga mereka merasa puas dan dapat menjadi pelanggan yang loyal (Supranto, 1997).

Dimana situasi konsumen adalah faktor lingkungan yang menyebabkan suatu situasi dimana perilaku konsumen muncul pada waktu tertentu dan tempat tertentu (Mowen dan Minor, 2001).

Menurut Engel (1994) pengaruh lingkungan dapat dipandang sebagai pengaruh yang timbul dari faktor yang khusus untuk waktu dan tempat yang spesifik yang lepas dari karakteristik konsumen dan karakteristik objek.

Menurut McKnight terdapat tiga elemen yang membangun persepsi konsumen yaitu benevolence, integrity, competence.

\section{Benevolence}

Berarti seberapa besar seseorang percaya kepada penjual untuk berperilaku baik kepada konsumen. Benevolence merupakan kesediaan penjual untuk melayani kepentingan konsumen.

\section{Integrity}

Integrity (integritas) adalah seberapa besar keyakinan seseorang terhadap kejujuran penjual untuk menjaga dan memenuhi kesepakatan yang telah dibuat kepada konsumen.

\section{Competence}

Competence (kompetensi) adalah keyakinan seseorang terhadap kemampuan yang dimiliki penjual untuk membantu konsumen dalam melakukan sesuatu sesuai dengan yang dibutuhkan konsumen tersebut. Esensi dari kompetensi adalah seberapa besar keberhasilan penjual untuk menghasilkan 
hal yang diinginkan oleh konsumen. Inti dari kompetensi adalah kemampuan penjual untuk memenuhi kebutuhan konsumen.

Tingkat merek produk dalam membangun persepsi konsumen menurut Gary Hamel (1996) yaitu:

\section{Recognition}

Yaitu tingkat dikenalnya sebuah merek oleh konsumen. Jika sebuah merek tidak dikenal, maka produk dengan merek tersebut harus dijual dengan mengandalkan harga yang murah.

\section{Reputation}

Yaitu tingkat atau status yang cukup tinggi bagi sebuah merek karena lebih terbukti memiliki track record yang baik.

\section{Affinity}

Yaitu suatu emosional relationship yang timbul antara sebuah merek dengan konsumenya, sebuah produk dengan merek yang disukai oleh konsumen akan lebih mudah dijual dan sebuah produk dengan persepsi memiliki kualitas yang tinggi akan mempunyai reputasi yang baik.

\section{Loyalty}

Yaitu menyangkut seberapa besar kesetiaan konsumen yang menggunakan merek bersangkutan.

\section{Implikasi Praktis}

1. Fokuskan pada Lingkungan dan Gaya Hidup Konsumen

Dengan menawarkan produk perusahaan kepada para pelanggan, tentu yang pertama kali dipikirkan oleh para pelanggan adalah apa manfaat produk itu bagi mereka. Produk perusahaan harus mempunyai manfaat yang nyata terhadap kehidupan mereka. Apakah produk tersebut mampu memecahkan masalah sehari-hari yang mereka hadapi misalnya. Atau apakah produk perusahaan bisa meningkatkan karir mereka. Atau mungkin produk yang perusahaan tawarkan bisa memberikan mereka penghasilan yang lebih tinggi dibandingkan yang mereka terima sekarang. Berikan manfaat yang nyata dan masuk akal yang sesuai dengan lingkungan dan gaya hidup pelanggan.

2. Buat Komunikasi bisnis yang Sederhana

Tujuan

perusahaan

mengkomunikasikan produk kepada pelanggan adalah agar mereka dapat dengan cepat memahami informasi yang ingin perusahaan sampaikan kepada mereka. Jika pesan yang perusahaan sampaikan terkesan rumit, banyak bahasa teknis dan berat, bagaimana mungkin mereka akan memahami produk yang perusahaan tawarkan kepada mereka. Jika mereka sudah tidak paham, tidak akan mungkin terbentuk persepsi yang perusahaan harapkan pada benak mereka.

Makanya gunakan bahasa yang sederhana namun jelas dan dapat dimengerti oleh semua kalangan. Buat slogan yang singkat dan berhubungan dengan produk atau jasa yang ditawarkan. Apakah bahasa yang perusahaan gunakan dapat dimengerti oleh orang bekerja kantoran ataupun sebagai wiraswasta.

\section{Tekankan Pada Nilai yang Ditawarkan}

Maksudnya adalah jangan terlalu membombardir pelanggan perusahaan dengan informasi-informasi yang lebih bersifat teknis. Sebuah nilai yang baik mampu memberikan kualitas emosional kepada para pelanggannya. Sebuah nilai yang baik mampu memberikan rasa aman, rasa pintar, atau bahkan rasa nyaman yang dirasakan oleh para pelanggan yang menggunakan produk-produk tersebut.

Karenanya dengan melakukan tekanan nilai yang perusahaan berikan kepada pelanggan perusahaan. Dengan begitu, persepsi produk perusahaan akan kuat tertanam dibenak mereka.

\section{Membangun Citra yang Postif}

Citra perusahaan menggambarkan nilai, kepercayaan dan produktivitas perusahaan, sehingga menghasilkan reputasi positif di mata publik. Citra 
perusahaan yang positif dapat mempengaruhi persepsi konsumen terhadap perusahaan, bertanggung jawab untuk meningkatkan penjualan dan bisnis bagi perusahaan.

Citra perusahaan yang positif mempengaruhi persepsi konsumen terhadap perusahaan, bertanggung jawab untuk meningkatkan penjualan dan bisnis bagi perusahaan.

Membangun citra perusahaan membutuhkan proses yang panjang, karena citra merupakan semua persepsi yang dibentuk oleh konsumen, dengan cara memproses informasi dari berbagai sumber sepanjang waktu. Citra perusahaan dapat dikatakan sebagai persepsi masyarakat dari adanya pengalaman, kepercayaan, perasaan, dan pengetahuan masyarakat itu sendiri, terhadap sebuah perusahaan. Citra perusahaan dibentuk oleh masyarakat, dari upaya komunikasi dan keterbukaan perusahaan dalam usaha membangun citra yang positif.

\section{SIMPULAN}

Dapat dibuat kesimpulan dari hasil penelitian adalah sebagai berikut ini:

1. Dimana Rata-rata persepsi kelompok pekerjaan wiraswasta, ibu rumah tangga dan lain-lain $(4,0852)$ lebih baik dibandingkan kelompok pekerjaan pegawai negeri dan pegawai swasta $(3,9417)$ mengenai kualitas produk air minum isi ulang.

2. Uji $\mathrm{F}$ menunjukan kalau varians kedua kelompok terhadap kualitas air minum isi ulang adalah sama $(\mathrm{P}$ value $=0,726)$.

3. Uji $\mathrm{T}$ menunjukan bahwa nilai $\mathrm{P}=0,035$ untuk uji 2-sisi. Karena $\mathrm{P}$ valuenya lebih kecil dari $\alpha=0,05$. Secara statistik terdapat perbedaan yang nyata antara ratarata persepsi konsumen yang bekerja sebagai wiraswasta, ibu rumah tangga dan lain-lain dengan konsumen yang bekerja sebagai pegawai negeri dan pegawai swasta terhadap kualitas produk air minum isi ulang.

4. Rata-rata persepsi konsumen kelompok pekerjaan wiraswasta, ibu rumah tangga dan lain-lain $(4,0620)$ lebih baik dibandingkan konsumen kelompok pekerjaan pegawai negeri dan pegawai swasta $(3,8903)$ mengenai harga produk air minum isi ulang.

5. Uji F menunjukan kalau varians kedua kelompok terhadap kualitas air minum isi ulang adalah sama $(\mathrm{P}$ value $=$ $0,207)$.

6. Uji $\mathrm{T}$ menunjukan bahwa nilai $\mathrm{P}=$ 0,014 untuk uji 2-sisi. Karena P valuenya lebih kecil dari $\alpha=0,05$. Secara statistik terdapat perbedaan yang nyata antara rata-rata persepsi konsumen yang bekerja sebagai wiraswasta, ibu rumah tangga dan lain-lain dengan konsumen yang bekerja sebagai pegawai negeri dan pegawai swasta terhadap harga produk air minum isi ulang.

7. Rata-rata persepsi konsumen kelompok pekerjaan wiraswasta, ibu rumah tangga dan lain-lain $(4,0231)$ lebih baik dibandingkan konsumen kelompok pekerjaan pegawai negeri dan pegawai swasta (3.8486) mengenai kemasan produk air minum isi ulang.

8. Uji $F$ menunjukan kalau varians kedua kelompok terhadap kualitas air minum isi ulang adalah tidak sama $(\mathrm{P}$ value $=$ 0,038).

9. Uji $\mathrm{T}$ menunjukan bahwa nilai $\mathrm{P}=$ 0,017 untuk uji 2-sisi. Karena P valuenya lebih kecil dari $\alpha=0,05$. Secara statistik terdapat perbedaan yang nyata antara rata-rata persepsi konsumen yang bekerja sebagai wiraswasta, ibu rumah tangga dan lain-lain dengan konsumen yang bekerja sebagai pegawai negeri dan pegawai swasta terhadap harga produk air minum isi ulang.

\section{DAFTAR RUJUKAN}

Assael, H. 2002. Consumers Behavior and Marketing Action, Edisi 3, Kent Publishing Company, Boston Massachusset, AS.

Boyd W, Walker Orville, C Larreche, Claude Jean. 2000. Managemen 
Pemasaran: Suatu Pendekatan Strategis dengan Orientasi Global (Terjemahan). Erlangga. Jakarta.

Brink, Annekie, A. Berndt. 2009. Relationship Marketing \& Customer Relationship Management. Juta and Company Ltd.

Engel, J.F., Blackwell, R.D. \& Miniard, P.W. 1994. Consumer Behaviour. 8 Edition. Dryden. Fort Worth. Falk P.

Hamel, Gary, P. Prahalad. 1996. Competing For the Future. Harvard Business Press.

Jr, Charles W. Lamb, Jr Joseph, F. Hair, Mcdaniel Carl. 2001. Pemasaran. Edisi 1 (Terjemahan). Salemba Empat. Jakarta.

Kotler, Philip. 2002. Marketing Management, The Millenium Edition. Prentice Hall. Inc.

Lee W. McKnight, Paul M. Vaaler, Raul L. Katz. 2002. Creative Destruction: Business Survival Strategies in the Global Internet Economy. MIT Press.
Mowen, John. C., Michael Minor. 2001. Consumer Behavior: A Framework. Prentice Hall.

R.V Foster, Timothy. 1999. 101 Cara Meningkatkan Kepuasan Pelanggan. Edisi I (Terjemahan). Elex Media Komputindo. Jakarta.

Simamora, Henry. 2000. Manajemen Pemasaran Internasional. Salemba Empat. Jakarta.

Supranto, J. 1997. Pengukuran Tingkat Kepuasan Pelanggan Untuk Menaikkan Pangsa Pasar. Rineka Cipta. Jakarta.

Swasta, Basu. 2000. Manajemen Pemasaran. Liberty. Jakarta.

Umar, Husein. 2003. Studi Kelayakan Binis, Edisi 2, Gramedia. Jakarta. 